\title{
Impact of Environmental Factors on Macrophomina phaseolina causing Charcoal Rot of Soybean
}

\author{
T. Surya Teja ${ }^{1^{*}}$, D. S. Kelayia ${ }^{2}$ and R. Asha ${ }^{2}$ \\ ${ }^{1}$ Department of Plant Pathology, ${ }^{2}$ Main Oilseeds Research Station, Junagadh Agricultural \\ University, Junagadh, Gujarat, India \\ *Corresponding author
}

\section{A B S T R A C T}

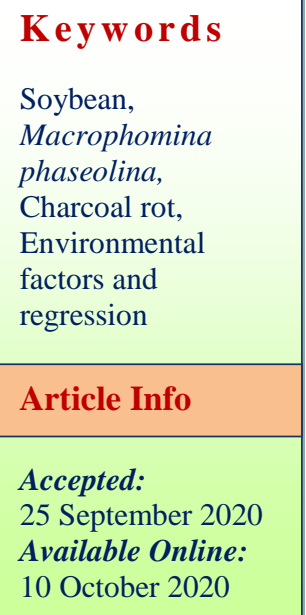

The influence of abiotic factors on the charcoal rot incidence caused by the fungus $M$. phaseolina has been analysed statistically by subjecting weekly weather data with disease incidence data to Multiple Linear Regression analysis. It revealed that there was no significant relation was observed in rainfall and minimum temperature with disease incidence. There was a progressive increase and maximum per cent disease intensity was recorded at optimum high temperature of $28-35^{0} \mathrm{C}$, relative humidity of $65-80 \%$, soil temperature at $5 \mathrm{~cm}\left(35.6^{0} \mathrm{C}\right)$ and $10 \mathrm{~cm}\left(32.2^{\circ} \mathrm{C}\right)$. It was congenial for the pathogen to multiply and infect the host.

\section{Introduction}

Soybean (Glycine max-Linn.) is a leguminous and self-pollinated crop which helps in fixation of nitrogen by establishing a symbiotic relationship with the bacterium Bradyrhizobium japonicum. Soybean is cultivated across the continents except Europe and Australia over an area of about 120 million ha. USA, Brazil, Argentina, China, and India contribute about 89 per cent of the total soybean production in the world. It is often called as a wonder crop due to its omniusage in various industries for manufacturing of soya milk, soya flour, soya cake, biscuits, varnish, paints, etc. Being used as vegetable meat, it has wide economic usage in synthesis of oil, vegetable ghee, etc.

In India, soybean has emerged as an important oilseed crop. Gujarat is one of the soybean cultivated state where continuous increase in area and production of the crop since last few years of adoption as for 
commercial cultivation. Different diseases are known to occur on soybean. Amongst them, charcoal rot caused by Macrophomina phaseolina is an important destructive diseases of soybean in Saurashtra region of Gujarat. Due to global warming, and potential climate abnormalities associated with it, crops typically encounter an increased number of abiotic and biotic stress combinations, which influence the occurrence and spread of pathogens, insects, and weeds (Pandey et al., 2017 and Peters et al., 2014).

Anabiotic stress preceeds the biotic stress factor in sequence, predispose the plants to the subsequent stress. For example, drought predisposes Sorghum bicolor (sorghum) to Macrophomina phaseolina (Goudarzi et al., 2011). Charcoal rot of soybean also known as dry weather wilt is caused by Macrophomina phaseolina.

The losses due to charcoal rot usually depend upon conducive soil and environmental conditions, inoculum quantity and host susceptibility. Effective management strategies can be developed by understanding the role of soil and environmental conditions (Bashir 2017). Present experiment was conducted to assess the impact of environmental factors on the charcoal rot incidence in soybean crop during kharif 2019.

\section{Materials and Methods}

The weekly meteorological data has been recorded to study the impact of different abiotic factors like temperature, relative humidity, soil temperature and rain fall on disease incidence. The five random quadrate of unit square meters were selected from the plot and tagged. All other agronomical practices have been followed as per the scientific recommendations. The crop under the experiment were kept free from insecticidal sprays throughout the crop season. The data on charcoal rot has been recorded by counting the number of infected plant in each quadrate at weekly interval from initiation of disease appearance till the harvest of the crop. Per cent disease incidence was calculated by using the following formula.

PDI $=\frac{\text { Number of infected plants }}{\text { Total number of plants observed }} \times 100$

The influence of abiotic factors on the charcoal rot incidence caused by the fungus $M$. phaseolina has been analysed statistically by subjecting weekly weather data with disease incidence data to Multiple Linear Regression analysis. (Gomez and Gomez, 1984). The following data represents the maximum and minimum temperature, soil temperature, relative humidity respectively and rainfall from the week of sowing to harvesting which was used to study the impact over Macrophomina growth (Table 1).

\section{Results and Discussion}

Observations for the disease incidence were recorded at weekly intervals till the harvesting. The correlation between the charcoal rot intensity and the concerned parameters (mean of maximum and minimum temperature, soil temperature, relative humidity and total rainfall) corresponding to the meteorological weeks were determined by multiple linear regression (MLR) equation.

The crop was sown on $6^{\text {th }}$ August, 2019 and the first disease incidence $(4.54 \%)$ was recorded after 28 days of sowing $\left(36^{\text {th }}\right.$ standard week) at a seedling stage.

The progress of the disease during Kharif crop season was gradually increased from $5^{\text {th }}$ September, 2019 (4.54\%) and reaches peak stage at $11^{\text {th }}$ November, $2019 \quad(25.54 \%)$ at harvesting stage. The disease incidence was started from the end of $4^{\text {th }}$ week onwards, 
reached its peak at $13^{\text {th }}$ week and became constant till harvest (Fig 1).

The data on per cent disease incidence in relation to environmental factors was subjected to step down multiple linear regression and the best fitted equation was obtains as

$\mathrm{Y}=42.30+4.22 \mathrm{x}_{1}{ }^{*}-7.25 \mathrm{x}_{2}+3.19 \mathrm{x}_{3}{ }^{*}+$ $3.99 x_{4}{ }^{*}-0.87 x_{5}{ }^{*}-0.05 x_{6}$
The coefficient of determination $\left(R^{2}\right)$ value indicates the proportion of total variation in output explained by the independent variables. The $\mathrm{R}^{2}$ value obtained as 0.81 which showed that maximum temperature, minimum temperature, soil temperature at 5 $\mathrm{cm}$, soil temperature at $10 \mathrm{~cm}$, relative humidity and rainfall caused significant variation in per cent disease incidence to the extent of 81 per cent.

Table.1 Weekly meteorological data to compare with the growth of M. phaseolina under field condition

\begin{tabular}{|c|c|c|c|c|c|c|}
\hline $\begin{array}{c}\text { Standard } \\
\text { week }\end{array}$ & $\begin{array}{c}\text { maximum } \\
\text { temperature } \\
\mathbf{( \mathbf { 0 }} \mathbf{C}\end{array}$ & $\begin{array}{c}\text { Minimum } \\
\text { temperature } \\
\mathbf{( \mathbf { 0 } )}\end{array}$ & $\begin{array}{c}\text { Soil } \\
\text { temperature } \\
\text { at } \mathbf{5}^{\mathbf{0}}\end{array}$ & $\begin{array}{c}\text { Soil } \\
\text { temperature } \\
\text { at } \mathbf{1 0}^{\mathbf{0}} \mathbf{C}\end{array}$ & $\begin{array}{c}\text { Relative } \\
\text { humidity } \\
\text { max } \mathbf{( \% )}\end{array}$ & $\begin{array}{c}\text { Rainfall } \\
\text { in mm }\end{array}$ \\
\hline $\mathbf{3 2}$ & 28.89 & 25.53 & 30.61 & 28.17 & 95.86 & 180.60 \\
\hline $\mathbf{3 3}$ & 30.57 & 25.34 & 33.83 & 30.39 & 96.43 & 22.90 \\
\hline $\mathbf{3 4}$ & 32.43 & 24.83 & 36.49 & 32.57 & 89.57 & 3.90 \\
\hline $\mathbf{3 5}$ & 30.94 & 25.54 & 34.31 & 31.04 & 95.71 & 49.60 \\
\hline $\mathbf{3 6}$ & 31.07 & 25.36 & 33.24 & 30.80 & 94.43 & 248.00 \\
\hline $\mathbf{3 7}$ & 29.79 & 25.33 & 32.64 & 29.71 & 96.14 & 180.50 \\
\hline $\mathbf{3 8}$ & 32.56 & 25.09 & 35.61 & 32.20 & 88.71 & 24.60 \\
\hline $\mathbf{3 9}$ & 30.99 & 24.34 & 33.31 & 30.23 & 92.71 & 196.20 \\
\hline $\mathbf{4 0}$ & 32.54 & 23.93 & 36.31 & 32.74 & 87.43 & 36.80 \\
\hline $\mathbf{4 1}$ & 34.87 & 23.39 & 37.01 & 33.64 & 80.00 & 0.00 \\
\hline $\mathbf{4 2}$ & 35.24 & 22.71 & 37.33 & 33.17 & 77.14 & 1.00 \\
\hline $\mathbf{4 3}$ & 32.60 & 24.80 & 37.39 & 32.69 & 64.14 & 0.00 \\
\hline $\mathbf{4 4}$ & 34.04 & 23.69 & 38.99 & 34.96 & 79.57 & 4.40 \\
\hline $\mathbf{4 5}$ & 33.31 & 22.03 & 39.63 & 35.34 & 70.14 & 0.00 \\
\hline
\end{tabular}

Table.2 Multiple linear regression between disease incidence and environmental factors

\begin{tabular}{|c|c|c|}
\hline Weather parameters & Coefficient & Test of significance $(t)$ \\
\hline $\mathrm{X}_{1}$-Maximum temperature $\left({ }^{0} \mathrm{C}\right)$ & 4.22 & $4.19^{*}$ \\
\hline $\mathrm{X}_{2}$-Minimum temperature $\left({ }^{0} \mathrm{C}\right)$ & -7.25 & $-4.54^{\mathrm{NS}}$ \\
\hline $\mathrm{X}_{3}$-Soil temperature at5cm $\left({ }^{0} \mathrm{C}\right)$ & 3.19 & $4.71^{*}$ \\
\hline $\mathrm{X}_{4}$-Soil temperature at $10 \mathrm{~cm}\left({ }^{0} \mathrm{C}\right)$ & 3.99 & $4.49^{*}$ \\
\hline $\mathrm{X}_{5}$-Relative humidity (\%) & -0.87 & $7.11^{*}$ \\
\hline $\mathrm{X}_{6}$-Rainfall (mm) & -0.05 & $-1.91^{\mathrm{NS}}$ \\
\hline
\end{tabular}

Note: *Indicates significant at the 0.01 level.

${ }^{N S}$ Indicates non-significant 
Fig.1 Plant disease incidence (\%) from $1^{\text {st }}$ to $14^{\text {th }}$ week of soybean crop

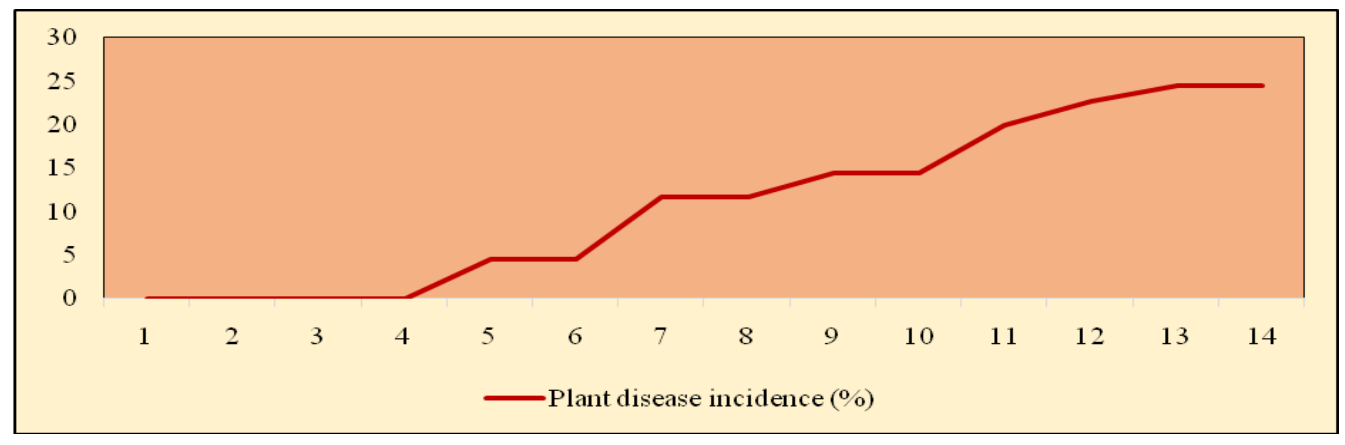

Fig.2 Relation of disease incidence $(\%)$ to the maximum temperature $\left({ }^{0} \mathrm{C}\right)$

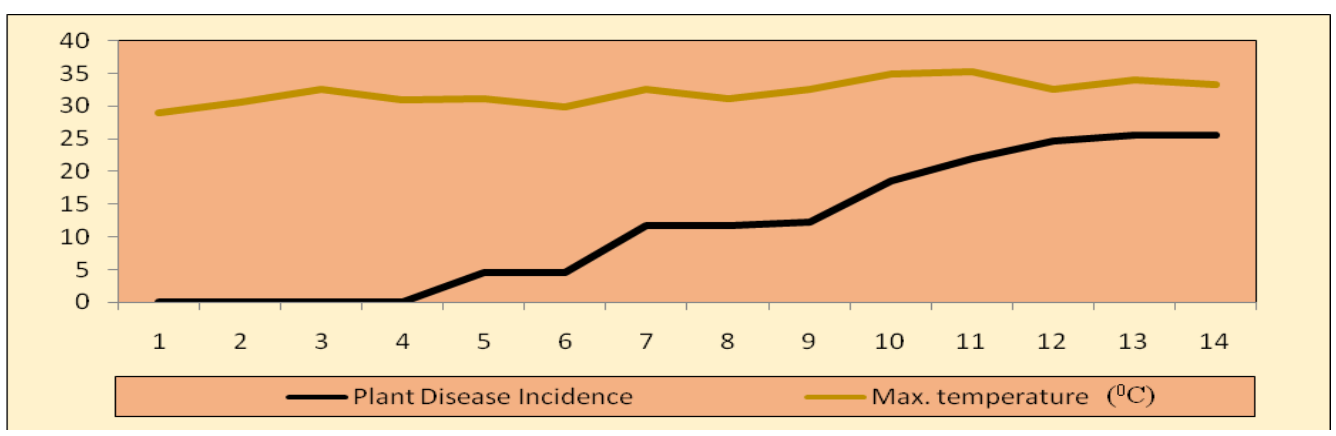

Fig.3 Relation of disease incidence $(\%)$ to the minimum temperature $\left({ }^{0} \mathrm{C}\right)$

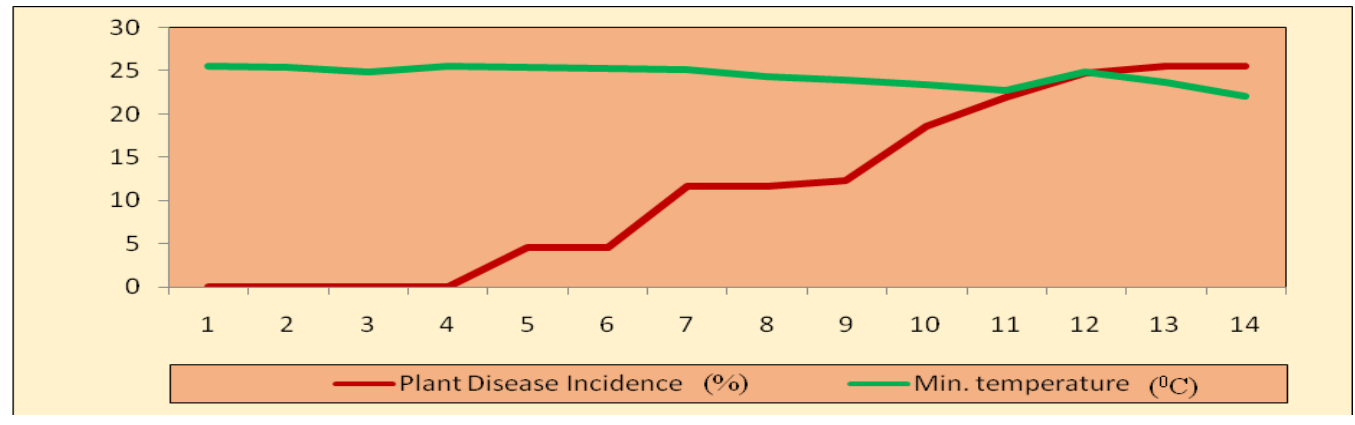

Fig.4 Relation of disease incidence $(\%)$ to the soil temperature $\left({ }^{0} \mathrm{C}\right)$ at $5 \mathrm{~cm}$ depth

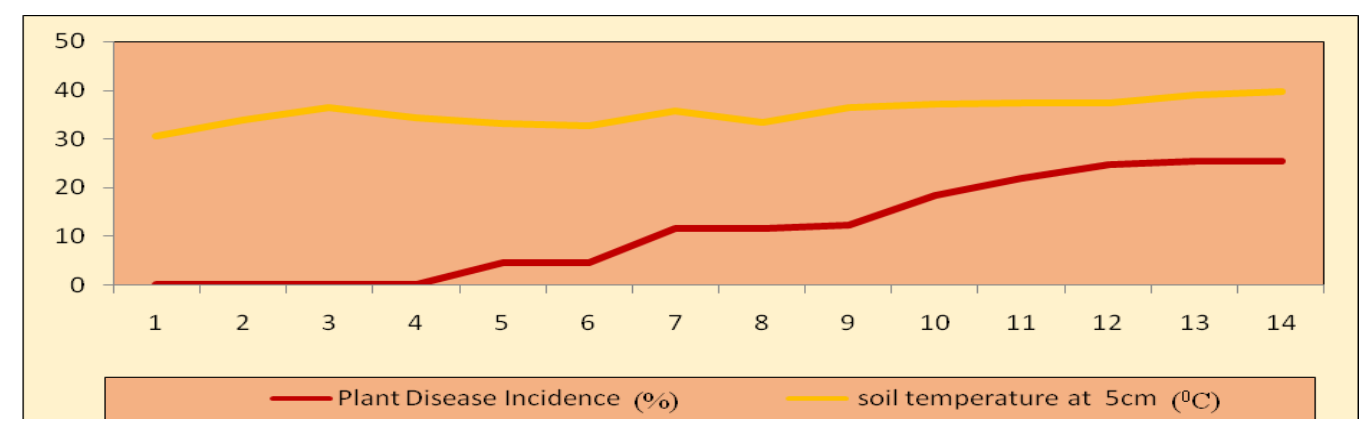


Fig.5 Relation of disease incidence $(\%)$ to the soil temperature $\left({ }^{0} \mathrm{C}\right)$ at $10 \mathrm{~cm}$ depth

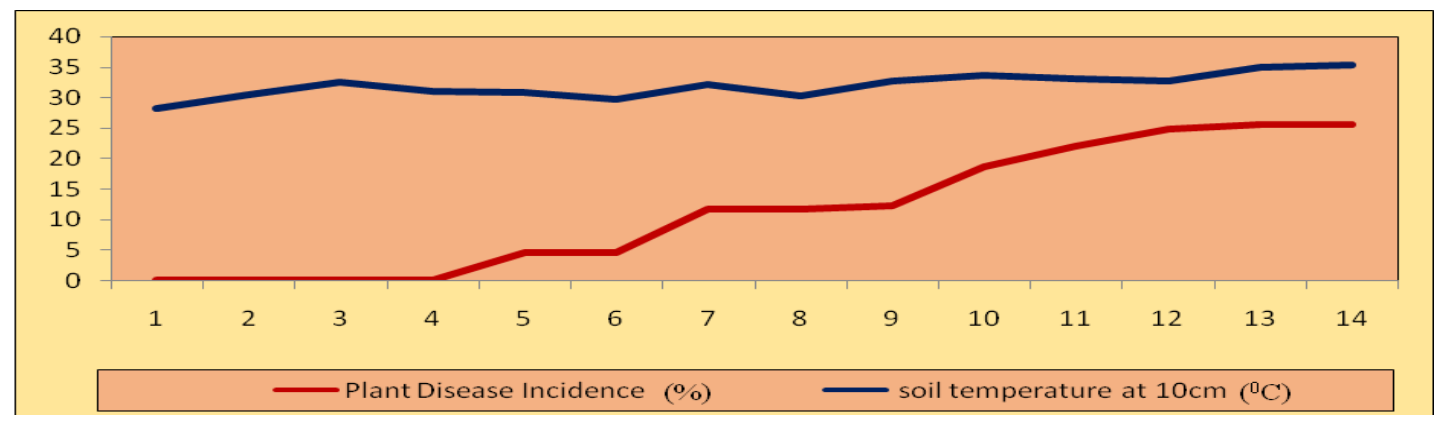

Fig.6 Relation of disease incidence (\%) to the relative humidity (\%)

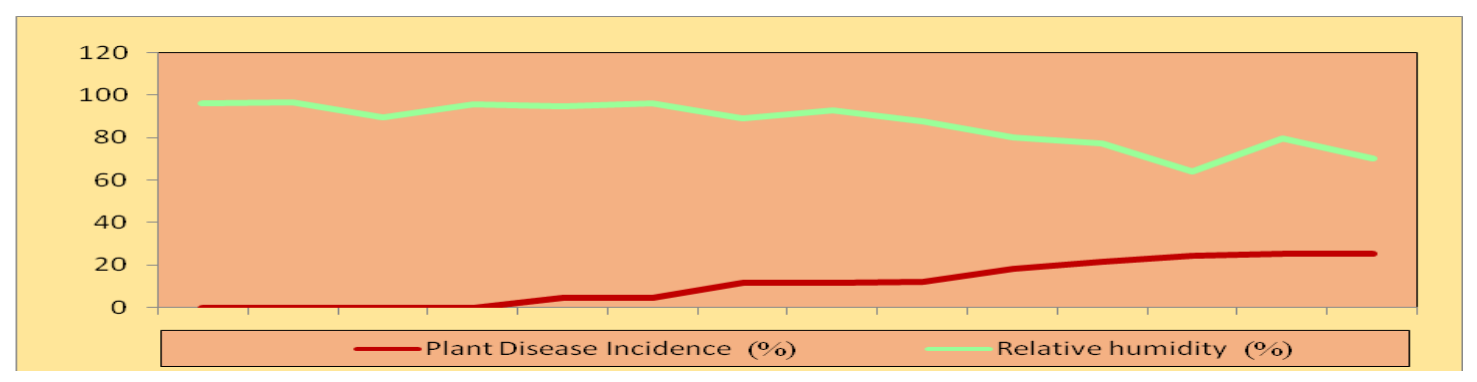

Fig.7 Relation of disease incidence (\%) to the rainfall (mm)

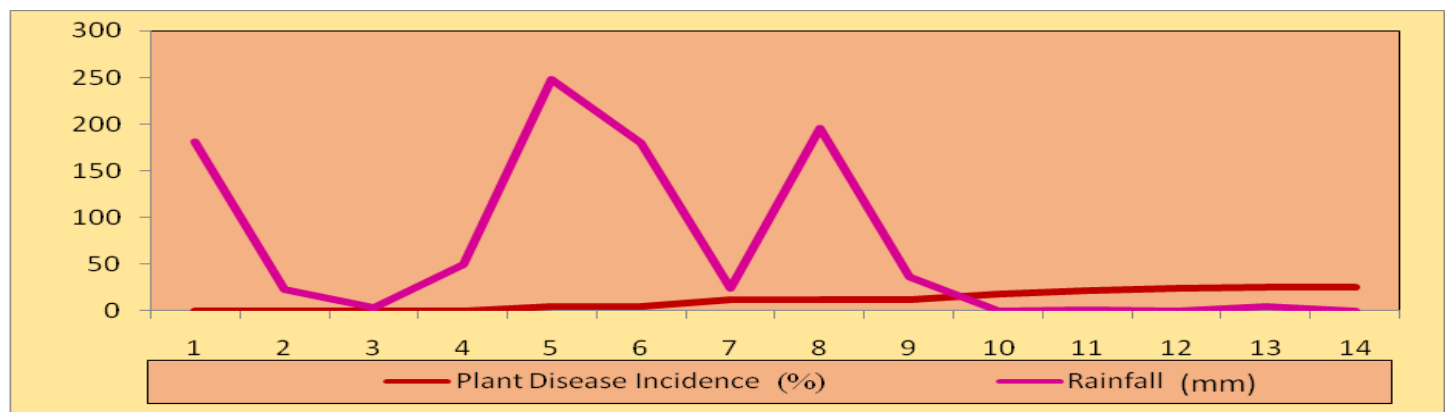

\section{Maximum temperature}

At $1 \%$ level of significance (LOS), the maximum temperature showed positive significant correlation with charcoal rot incidence. From the regression equation, it was noticed that the disease intensity increased by 4.22 times with a $1{ }^{0} \mathrm{C}$ raise in maximum temperature (Fig 2).

Minimum temperature

A non-significant negative correlation was observed between charcoal rot incidence and minimum temperature indicating that the minimum temperature has no role in charcoal rot incidence (Fig 3).

\section{Soil temperature at $5 \mathrm{~cm}$}

The soil temperature at $5 \mathrm{~cm}$ level was found to have a significant positive correlation with charcoal rot incidence at $1 \%$ LOS. Further, an increase in the disease incidence by 3.19 times with a raise in every $1^{0} \mathrm{C}$ of soil temperature at $5 \mathrm{~cm}$ was noticed from the regression equation (Fig 4). 


\section{Soil temperature at $10 \mathrm{~cm}$}

At $1 \%$ LOS, a significant positive correlation was observed between the soil temperature at $10 \mathrm{~cm}$ and charcoal rot incidence. From the regression equation, it was understood that charcoal rot intensity increased by 3.99 times with a $1^{0} \mathrm{C}$ raise in soil temperature at $10 \mathrm{~cm}$ (Fig 5).

\section{Relative humidity}

The RH was found significant at $1 \%$ LOS and was found negatively correlated with the disease incidence. The regression equation indicated that with every $1 \%$ increase in the R.H disease incidence decreased by 0.87 times (Fig 6).

\section{Rainfall}

The rainfall $(\mathrm{mm})$ was observed to have nonsignificant negative correlation with the disease incidence (Fig 7).

The disease was initially appeared during the first week of September (1 MAS) when the maximum temperature of $31.07^{\circ} \mathrm{C}$ with $94.43 \%$ relative humidity existed. Gradual progression of the disease incidence with time was observed till the last week of October where $33.31^{\circ} \mathrm{C}$ maximum temperature and $70.14 \%$ relative humidity was recorded. Later, the disease incidence was observed to be constant till the harvest. The result of present study revealed that the optimum high temperature of $28-35^{\circ} \mathrm{C}$ and $\mathrm{RH}$ of $65-80 \%$ were congenial for the pathogen to multiply and infect the host. Since M. phaseolina was reported to be a drought favouring disease, soil temperature at $5 \mathrm{~cm}\left(35.6^{\circ} \mathrm{C}\right)$ and $10 \mathrm{~cm}$ $\left(32.2^{0} \mathrm{C}\right)$ with subsequently low soil moistures at their respective depths during the $38^{\text {th }}$ standard week might have influenced the pathogen to attack the stressed host at large proportions resulting in higher disease incidence. Though no significant relation observed between disease incidence and rainfall, the disease was found to persist even in the last four weeks during which the crop received reduced rainfall.

The similar results were reported by Chaudhary (2017), who reported that maximum temperature, relative humidity, and soil temperature at $10 \mathrm{~cm}$ depth were the important factors for dry root rot disease development in soybean. Results by Mishra (2017) also revealed that maximum temperature $\left(31.2^{\circ} \mathrm{C}\right.$ to $\left.32.3^{\circ} \mathrm{C}\right)$, low $\mathrm{RH}$ and rainfall were congenial for the pathogen to flourish. Similar results observed by Patidar (2013) also reported the significant relationship of maximum temperature, soil temperature and relative humidity with charcoal rot incidence. Ansari (2010) recorded high disease incidence at pod formation and filling stage when the temperature was at $25-35^{\circ} \mathrm{C}$.

In conclusion the epidemiology study of the pathogen reported that the optimum high temperature of $28-35^{\circ} \mathrm{C}, \mathrm{RH}$ of $65-80 \%$,soil temperature at $5 \mathrm{~cm}\left(35.6^{\circ} \mathrm{C}\right)$ and $10 \mathrm{~cm}$ $\left(32.2^{0} \mathrm{C}\right)$ were congenial for the pathogen to multiply and infect the host. The change in the weather leads to change in habitat of the pathogen.

\section{References}

Gomez, K. A. and Gomez, A. A. (1984). Statistical Procedures for Agricultural Research, $2^{\text {nd }}$ Ed. John Wiley and Sons. 382-387.

Goudarzi S., Banihashemi Z., Maftoun M. (2011). Effect of salt and water stress on root infection by Macrophomina phaseolina and ion composition in shoot in sorghum. Iran Journal of Plant Pathology. 47: 69-83.

Peters K., Breitsameter L., Gerowitt B. 
(2014). Impact of climate change on weeds in agriculture: a review. Agricultural Sustainable Development. 34: 707-721.

Pandey, P.; Irulappan, V.; Bagavathiannan, M. V. and Kumar, M. S. (2017). Impact of combined abiotic and biotic stresses on plant growth and avenues for crop improvement by exploiting physio-morphological traits. Frontiers in plant science. 8: 537.

Chaudhary, D. H. (2017). Symptomatology, epidemiology and bioassay study of dry root rot of soybean. M.Sc. (Agri.) Thesis. Navsari Agricultural University, Navsari.

Mishra, P. K. (2017). Management of root rot of cluster bean (Cyamopsis tetragonoloba L.) incited by Rhizoctonia bataticola. M.Sc. (Agri.) Thesis. Sri Karan Narendra
Agriculture University, Jobner.

Patidar, J. K. (2013). Studies on charcoal rot of soybean (Glycine max (L.) Merrill) caused by Macrophomina phaseolina (Tassi) Goid (Rhizoctonia bataticola (Taub.) Butler) with special reference to its epidemiology and management [Glycine $\max$ (L.) Merrill]. M.Sc. (Agri.) Thesis. Rajmata Vijayaraje Scindia Krishi Vishwa Vidyalaya, Gwalior (M.P.).

Ansari, M. M. (2010). Integrated management of charcoal rot of soybean caused by Macrophomina phaseolina (Tassi) Goid. Soybean Research. 8: 39-47.

Bashir, M. R. (2017). Impact of Global Climate Change on Charcoal Rot of Sesame Caused by Macrophomina phaseolina. Journal of Horticulture.4: 106.

\section{How to cite this article:}

Surya Teja, T., D. S. Kelayia and Asha, R. 2020. Impact of Environmental Factors on Macrophomina phaseolina causing Charcoal Rot of Soybean. Int.J.Curr.Microbiol.App.Sci. 9(10): 3784-3790. doi: https://doi.org/10.20546/ijcmas.2020.910.435 